\title{
83. Sequential File Update
}

One of the commonest problems to deal with is bringing a sequential file up-todate with new information.

As it is not possible to add new information directly into the middle of a sequential file - it is necessary to create a new up-to-date file.

This is generally done by first putting all the changes into a transaction file (i.e. a file of changes) - sorting them into order and then using data from the old main file together with the transaction file to create a new main file.

For example the main student file for a class contains 7 students' records showing their names and ages:

$\begin{array}{ll}\text { ANDERSON } & 20 \\ \text { CHOWDURY } & 19 \\ \text { DAVIS } & 21 \\ \text { EDWARDS } & 17 \\ \text { OLADEDJU } & 18 \\ \text { ROBERTS } & 19 \\ \text { WILLIAMS } & 20\end{array}$

3 new students join the class, 2 leave and 1 is found to have his age recorded incorrectly - so a transaction file is created containing the name, age if necessary and transaction type (i.e. Insert in the file, Delete from the file or Amend a Record):

$\begin{array}{lll}\text { ROGERS } & 18 & \text { I } \\ \text { DAVIS } & & \text { D } \\ \text { ANDREWS } & 19 & \text { I } \\ \text { WILLIAMS } & & \text { D } \\ \text { CHENG } & 20 & \text { I } \\ \text { ROBERTS } & 20 & \text { A }\end{array}$

This needs to be sorted into order - before it can be used to update the main file:

$\begin{array}{lll}\text { ANDREWS } & 19 & \text { I } \\ \text { CHENG } & 20 & \text { I } \\ \text { DAVIS } & & \text { D } \\ \text { ROBERTS } & 20 & \text { A } \\ \text { ROGERS } & 18 & \text { I } \\ \text { WILLIAMS } & & \text { D }\end{array}$

Now the update program will use information from the main file together with the transaction file to create a new main file:

$\begin{array}{ll}\text { ANDERSON } & 20 \\ \text { ANDREWS } & 19 \\ \text { CHENG } & 20 \\ \text { CHOWDURY } & 19 \\ \text { EDWARDS } & 17 \\ \text { OLADEDJU } & 18 \\ \text { ROBERTS } & 20 \\ \text { ROGERS } & 18\end{array}$

